\title{
Water quality and emission rates of greenhouse gases in a treatment reedbed
}

\author{
K. Soosaar, M. Maddison \& Ü. Mander \\ Department of Geography, University of Tartu, Estonia
}

\begin{abstract}
The aim of this study was to estimate water purification capacity and greenhouse gas fluxes in a semi-natural reedbed receiving effluent from a wastewater treatment plant (WTP) in Lihula, which is located on the southern border of Matsalu National Park, Estonia. The values of $\mathrm{BOD}_{7}$ and $\mathrm{COD}$ in the treated water were low $\left(<8\right.$ and $<70 \mathrm{mgL}^{-1}$ respectively), whereas the COD level increased within the reedbed. The average concentrations of ammonia $\mathrm{N}$ and total $\mathrm{N}$ significantly decreased from the WTP outflow to the reedbed outflow (from 6.8 and 9 to 0.2 and $1.2 \mathrm{mg} \mathrm{L}^{-1}$ respectively). Nitrate and nitrite $\mathrm{N}$ levels were low but decreased along the flow. The average concentration of both $\mathrm{PO}_{4}-\mathrm{P}$ and total $\mathrm{P}$ in water decreased rapidly toward the reedbed outflow (from 2.8 and 3.2 to 0.04 and $0.09 \mathrm{mg} \mathrm{L}^{-1}$ respectively). Redox potential and dissolved $\mathrm{O}_{2}$ saturation showed the lowest values in the reedbed inflow. The $\mathrm{C}, \mathrm{N}$, and $\mathrm{P}$ concentration in soil decreased from the reedbed inflow towards the outflow. The average $\mathrm{N}_{2}$ and $\mathrm{N}_{2} \mathrm{O}$ fluxes from the reedbed were relatively low, varying from 4.0 to $16.1 \mathrm{mg} \mathrm{N}_{2} \mathrm{~m}^{-2} \mathrm{~h}^{-1}$ and from -5.0 to $3.7 \mu \mathrm{g} \mathrm{N}_{2} \mathrm{O} \mathrm{m}^{-2} \mathrm{~h}^{-1}$ respectively. The spatial-temporal variation of methane emission was great $\left(10.5-16397 \mu \mathrm{g} \mathrm{CH}_{4}\right.$ $\mathrm{m}^{-2} \mathrm{~h}^{-1}$ ), showing higher values in the inflow. The average $\mathrm{CO}_{2}$ emission from the reedbed varied from 14.3 to $334 \mathrm{mg} \mathrm{CO}_{2}-\mathrm{C} \mathrm{m}^{-2} \mathrm{~h}^{-1}$, being somewhat higher in the inflow area. Accumulation of $\mathrm{C}, \mathrm{N}$ and $\mathrm{P}$ in soil, increasing $\mathrm{COD}$ values and falling redox potential/dissolved $\mathrm{O}_{2}$ values in water, and higher $\mathrm{CH}_{4}$ and $\mathrm{CO}_{2}$ emission rates in the inflow site of the reedbed demonstrate the long-term impact of sewage loading.
\end{abstract}

Keywords: carbon dioxide, dinitrogen, methane, nitrous oxide, reedbed, seminatural wetland, wastewater, water quality. 


\section{Introduction}

Over several decades, wetlands have become increasingly frequently used throughout the world for primary, secondary or tertiary treatment of municipal, domestic, industrial or agricultural wastewaters [1-4]. In many countries, (semi-)natural wetlands serve as sinks for treated sewage for polishing [2], peatland restoration [5]. Several authors report the high efficiency of the removal of both nitrogen and phosphorus by these systems over a long period [6], even receiving raw sewage $[7,8]$. However, long-term loading with primarily treated or even untreated sewage will result in the accumulation of organic matter and heavy metals in wetlands, and saturation with phosphorus $[2,4,9,10]$. In several cases, new conventional treatment plants have been constructed, and the wetlands serve as secondary or tertiary treatment systems [11]. Little is known, however, about how these wetlands perform as water purifiers in changed conditions.

Reedbeds used as wastewater treatment wetland systems are able to improve the quality of wastewater (reduce the content of suspended solids, organic, $\mathrm{NH}_{3}{ }^{-}$, $\mathrm{NO}_{2}{ }^{-}, \mathrm{NO}_{3}{ }^{-}, \mathrm{N}_{\text {org }}, \mathrm{PO}_{4}{ }^{3-}, \mathrm{P}_{\text {tot }}$, metals, pathogens and change $\mathrm{pH}$ etc.) through various processes [2]. In such processes, organic materials and nitrogen are largely removed through volatilization to various gaseous substances, such as $\mathrm{CO}_{2}, \mathrm{CH}_{4}, \mathrm{~N}_{2}, \mathrm{~N}_{2} \mathrm{O}$, $\mathrm{NO}$ and $\mathrm{NH}_{3}$. The gases are emitted from waterlogged soil either by diffusion through the water or by active transport through the culms of wetland plants. Many species of emergent macrophytes such as Phragmites australis possess a convective flow mechanism; oxygen is transported to the roots, and gaseous microbial by-products are emitted into the atmosphere from plant roots [12]. Constructed and (semi-) natural wetlands are claimed to be effective water purifiers that have lower maintenance costs than conventional systems [4], but at the same time wetlands can contribute to global warming by emitting three important greenhouse gases (GHG): carbon dioxide $\left(\mathrm{CO}_{2}\right)$, methane $\left(\mathrm{CH}_{4}\right)$ and nitrous oxide $\left(\mathrm{N}_{2} \mathrm{O}\right)$ [13-24]. Nevertheless, we have not found in the literature data on GHG fluxes in reedbeds or other (semi-)natural wetland ecosystems used for the long-term after-treatment of municipal wastewater.

The objectives of this study were to (1) analyse the water purification efficiency of a reedbed ecosystem which has been used for decades as a sewage sink and nowadays receives effluent from a wastewater treatment plant (WTP), (2) estimate the fluxes of the main GHGs $\mathrm{N}_{2} \mathrm{O}, \mathrm{CO}_{2}$ and $\mathrm{CH}_{4}$, as well as $\mathrm{N}_{2}$ in this reedbed, comparing fluxes of the same gases from an adjacent grassland and forest ecosystem with similar soil conditions.

\section{Material and methods}

\subsection{Site description}

The study area is located on the western coast of Estonia, close to the southern border of Matsalu National Park, in Läänemaa County. The tertiary treatment 
system which we examine was designed for secondary wastewater treatment from the conventional treatment plant. The Lihula WTP $\left(58^{\circ} 41^{\prime} 21^{\prime \prime} \mathrm{N}\right.$; $\left.23^{\circ} 49^{\prime} 43^{\prime \prime} \mathrm{E}\right)$ was constructed in 1997 . Before that, municipal wastewater from the town of Lihula and a food processing factory (totalling about 2500 population equivalents, PE) was treated using only three stabilization ponds, which were full of sediments and obviously malfunctioned [25]. In 1994 the food processing factory was closed down. The new WTP, using a rotating biological contactor, treats wastewater from about $50 \%$ of the households and municipal buildings of Lihula (potentially about $800 \mathrm{PE} ; 750 \mathrm{~m}^{3} \mathrm{~d}^{-1}$ ) [25]. In addition to the WTP, the wastewater treatment system we studied includes a stabilization pond connected to the WTP by a ditch, a ditch from the pond to semi-natural reedbed and a reedbed system that finally serves as the treatment wetland (Fig. 1).

The Lihula-Matsalu reedbed ( $7 \mathrm{ha}$ ), located about 2.6-3.8 km northwest from the WTP, is a former shallow bay in the Baltic Sea formed on the Silurian

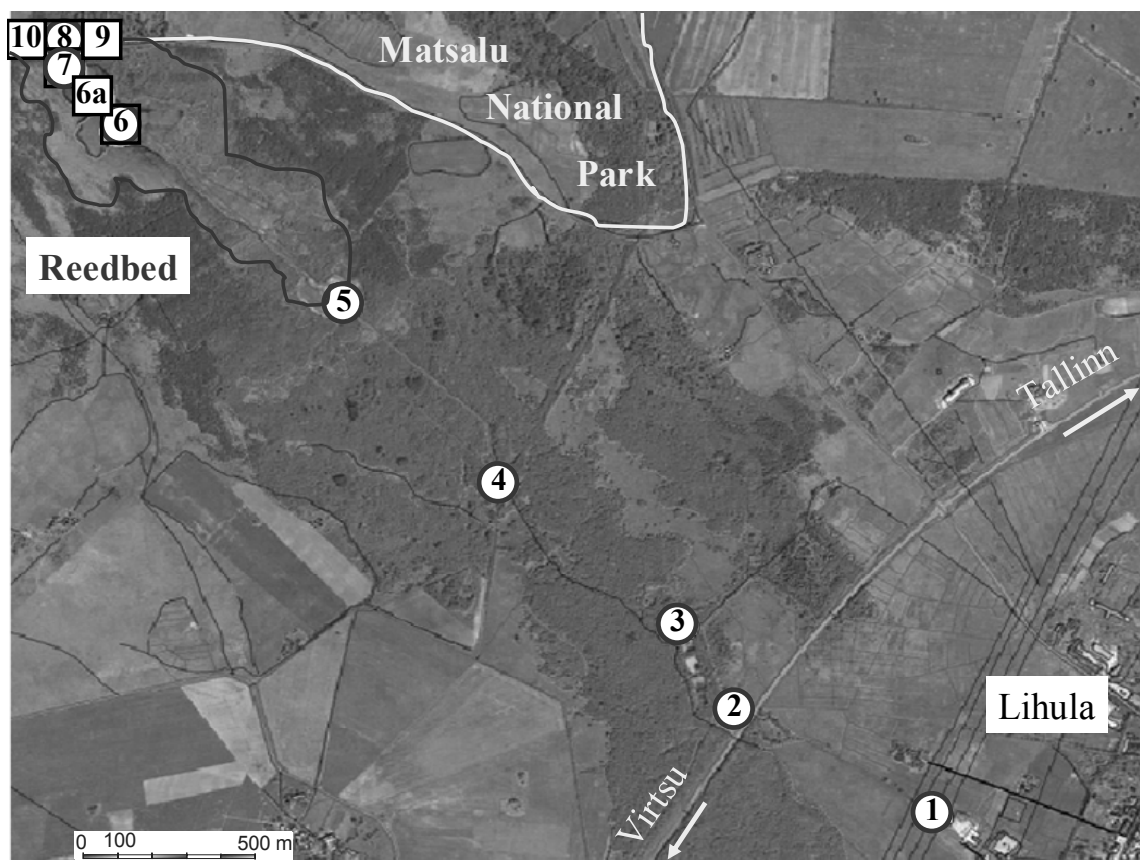

Figure 1: Location of sampling sites in the study area on the southern border of Matsalu National Park, Estonia: 1 - outflow from the wastewater treatment plant, 2 - stabilization pond inflow, 3 stabilization pond outflow, 4 - inflow ditch (Inflow ditch), 5 reedbed inflow, 6 - wet reedbed, $6 \mathrm{a}$ - dry reedbed, 7 - reedbed outflow, 8 - outflow ditch, 9 - forest, 10 - grassland. Circles water sampling sites, quadrangles - gas and soil sampling sites. The names of the water sampling sites used in Figures 2-4 are given in parentheses. 
bedrock of relatively soft limestones and marls, and covered by a thin till layer (0.5-2 $\mathrm{m})$ of Weicshelian glaciation [26] that was repeatedly flooded and abraded by sea transgressions during the Holocene [27]. Due to postglacial uplift (up to $2.5 \mathrm{~mm}$ year $^{-1}$ in this particular region; [26]) the reedbed was isolated from the sea about 1000-1500 years ago. The soils of this flat reedbed plain are predominantly Mollic and Calcaric Gleysols [28] with clay content $>60 \%$ [29]. The common reed (Phragmites australis), the dominant macrophyte of the reedbed, forms patch-like stands of different density, followed by a few patches of cattails (Typha latifolia and T. angustifolia), sedges (Carex spp.) and other aquatic macrophytes. The area is regularly flooded (for about 4-6 months of the year). Water flows through the reedbed, forming several pathways of various volume and depth $(10-30 \mathrm{~cm})$. Similar reedbeds $2-5 \mathrm{~km}$ north and northwest of the study area belong to Matsalu National Park, which was founded in 1957 as a nature reserve and was renamed a national park in 2004. In 1976 the Matsalu NP was included in the list of wetlands of international importance under the Ramsar Convention. For comparison gaseous fluxes from adjacent mixed forest (Betula pendula, Pinus sylvestris and Picea abies dominate in tree stand) on the complex of Rendzi-Gleyic Leptosols and Calcari-Gleyic Regosols, and a Sesleria caerulea-site type semi-natural grassland on Mollic Gleysol (Fig. 1; [28]) were measured. The water regime of both forest and grassland is influenced by the drainage ditch leading the water from the reedbed to the Penijõgi River and the Matsalu Bay.

\subsection{Water sampling and analyses}

The water quality measurement sites were located along the flow path of treated municipal wastewater and were as follows (Fig. 1): (1) outflow from WTP, (2) stabilization pond inflow (900 $\mathrm{m}$ from the WTP along the floodpath), (3) stabilization pond outflow $(1100 \mathrm{~m}),(4)$ central course of connecting ditch (1970 $\mathrm{m}),(5)$ reedbed inflow $(2560 \mathrm{~m}),(6)$ middle section of reedbed (wet and dry reedbeds; $3210 \mathrm{~m})$ ), (7) reedbed outflow $(3470 \mathrm{~m})$, and $(8)$ outflow ditch (3770 $\mathrm{m})$. The sampling was carried out in April, June, August and October 2007 and in August 2008. In October 2007 additional samples were taken from the outflow of the stabilization pond and from the inflow ditch (Fig. 1), because there was no water flow in the outflow ditch in August 2007. The samples were transported in $1 \mathrm{dm}^{3}$ polyethylene bottles to the lab (Laboratory of Tartu Environmental Research Ltd), where the analyses were begun within $24 \mathrm{~h}$ of collection. From all the water samples $\mathrm{pH}, \mathrm{BOD}_{7}, \mathrm{COD}_{\mathrm{Cr}}, \mathrm{NH}_{4}^{+}-\mathrm{N}, \mathrm{NO}_{2}^{-}-\mathrm{N}, \mathrm{NO}_{3}^{-}-\mathrm{N}$, total $\mathrm{N}, \mathrm{PO}_{4}{ }^{3-}-$ $\mathrm{P}$, total $\mathrm{P}, \mathrm{SO}_{4}{ }^{2-}$ and $\mathrm{Ca}^{2+}$ were analyzed in accordance with the international methods for water analysis [30]. Dissolved oxygen and redox potential were measured in the field using a Marvet Junior Dissolved Oxygen Meter and CyberScan $\mathrm{pH} / \mathrm{mV} /{ }^{\circ} \mathrm{C}$ Meter $\mathrm{pH} 300$ Series.

\subsection{Gas sampling and analyses}

Short-time trace gas flux sampling was carried out using the closed-chamber method. The gas samples from the PVC chamber (diameter $50 \mathrm{~cm}$, height $50 \mathrm{~cm}$, 
volume 65,5 1), which is white (to avoid heating during applications) and opaque (to avoid photosynthesis), were collected using previously evacuated flasks (100 $\mathrm{mL}$ ) at 0 and $60 \mathrm{~min}$ after closing the top of the chamber. The surface area of each chamber was $0.196 \mathrm{~m}^{2}$, and the chamber was placed on a water-filled ring that had been permanently placed in the soil before collection. The gas samples were taken in 5 replicates from the middle (from both - wet and dry sites) and outflow of the reedbed, in 3 replicates from the grassland and in 2 replicates from the forest near the outflow ditch in April, June and August, all in 2007 (Fig. 1). The concentration of carbon dioxide $\left(\mathrm{CO}_{2}\right)$, methane $\left(\mathrm{CH}_{4}\right)$, and nitrous oxide $\left(\mathrm{N}_{2} \mathrm{O}\right)$ in the samples was determined in the laboratory of the Leibniz Centre for Agricultural Landscape Research (ZALF) in Müncheberg, Germany using an automated gas chromatographic system (ECD and FID detectors, modified according to [31]). The emission rates of trace gases were calculated as the difference of gas concentrations between the beginning and the end of measurements, corrected for the area and volume of the chamber [32].

Dinitrogen $\left(\mathrm{N}_{2}\right)$ emission was measured using the He-O method [17, 19, 33, 34]. Intact soil cores (diameter $6.8 \mathrm{~cm}$ and height $6 \mathrm{~cm}$ ) for analysis using the $\mathrm{H}$ $\mathrm{O}$ method were taken from the topsoil $(0-10 \mathrm{~cm})$ under the gas sampler (closed chamber) sites after gas sampling was completed. Soil samples were weighted, kept at low temperature $\left(4^{\circ} \mathrm{C}\right)$, and transported to the laboratory of ZALF. At the laboratory, the soil samples were placed in special stainless steel incubation vessels that could be sealed gas-tight to the surroundings. The soil cores within the incubation vessels were kept at the temperatures observed in the field. The $\mathrm{N}_{2}$ was replaced with an artificial gas mixture $\left(21.3 \% \mathrm{O}_{2}, 78,6 \% \mathrm{He}, 337 \mathrm{ppm} \mathrm{CO}_{2}\right.$, $374 \mathrm{ppb} \mathrm{N}_{2} \mathrm{O}, 1882 \mathrm{ppb} \mathrm{CH}_{4}$ and approximately 5 ppm $\mathrm{N}_{2}$ ). The new flow equilibrium was established by continuously flushing the vessel headspace with artificial gas mixture at $10 \mathrm{ml}$ per minute for 12 hours. $\mathrm{N}_{2}$ concentration was measured in the continuous gas flow 1 hour after closing the incubation headspace. The emission rate of $\mathrm{N}_{2}$ was calculated as the difference in gas concentrations (final accumulation value minus start continuous flow value) [34].

\subsection{Soil sampling and analysis}

In August 2008 soil was sampled from four gas sampling sites (6, 6a, 9, and 10, Fig. 1) as complex samples (20-30g soil sampled from five microsites located in a $0.5 \mathrm{~m}$ radius circle, mixed, dried at $60^{\circ} \mathrm{C}$, and considered as one sample) from $0-10 \mathrm{~cm}$ and $30-40 \mathrm{~cm}$ depths. In the Laboratory of Tartu Environmental Research Ltd the nitrogen and carbon concentration was analysed using the Elemental analyser, and phosphorus concentration using the ICP-OES spectrometer.

Soils from the inflow part were mostly Calcaric Gleysols with somewhat higher $\mathrm{Ca}$ concentration than the Mollic Gleysols that are predominant in the outflow part of the treatment reedbed.

\subsection{Statistical data analysis}

The normality of water and gas quality variables was verified using the Lilliefors' and Shapiro-Wilk's tests. Most of the water quality characteristics 
were normally distributed, whereas the gas fluxes showed skewed distributions. An analysis of variance (One-way ANOVA) was carried out for all data. The STATISTICA 7.0 software was used and the level of significance of $\alpha=0.05$ was accepted in all cases.

\section{Results and discussion}

\subsection{Performance of the Lihula wastewater treatment plant}

The actual loading of the WTP is only $80-100 \mathrm{~m}^{3} \mathrm{~d}^{-1}$ (the projected value is 750 $\mathrm{m}^{3} \mathrm{~d}^{-1}$ ), which is partly due to overestimated loading rates, leaking old pipe systems, the slower connecting of consumers to the WTP, and partly because of a decreasing number of inhabitants in Lihula town [25]. Therefore the average water quality in the outflow from the WTP met the quality requirements for $\mathrm{COD}, \mathrm{BOD}_{7}$ and total $\mathrm{N}$ (Table 1).

Table 1: Average values of main water quality indicators in the outflow from the Lihula WTP and water quality standards $\left(\mathrm{mg} \mathrm{L}^{-1}\right)$ for treated wastewater in Estonia [35].

\begin{tabular}{lrrrr}
\hline & COD & BOD $_{7}$ & Total P & Total N \\
\hline Average WTP outflow & 52 & 7 & 1.9 & 8.9 \\
Quality standards & 125 & 25 & $2(1)^{*}$ & $10^{* *}$ \\
\hline$*$ & In parenthesis is the standard for sensitive water bodies. & \\
$* *$ & $\begin{array}{l}\text { Recommended standard for constructed wetland outflow; for } \\
\text { <10000 inhabitants, official standard is not established. }\end{array}$
\end{tabular}

Nevertheless, the average total P level in the outflow was up to two times higher than the quality standards require for effluents discharged into sensitive water bodies like the Penijõgi River and shallow Matsalu Bay (Table 1). In June and August 2007 the total P levels in the WTP outflow exceeded the standard fourfold: 4.1 and $4.9 \mathrm{mg} \mathrm{L}^{-1}$ correspondingly.

\subsection{Water quality}

The saturation of dissolved oxygen in water showed high values in the outflow of the WTP and the inflow to the stabilization pond (on average up to $80 \%$, Fig. 2 ), which shows that the purification process in the rotating biological contactor is almost aerobic. The lowering of the $\mathrm{O}_{2}$ concentration in the outflow from the stabilization pond and the connecting ditch shows that the removal of sediments from the pond will be necessary in the near future.

A slight increase in the average level of dissolved oxygen saturation in the reedbed inflow (up to 60\%) and continued increase within the reedbed (up to $80 \%$ ) may indicate a dissolution effect from groundwater and lateral inflow. Redox potential followed a similar pattern to dissolved oxygen saturation (Fig. 2), however, due to high standard deviation values, this change was not 
significant. On the other hand, predominating negative values point to facultative conditions $(-100-15 \mathrm{mV})$ in the reedbed water [2].

Throughout the whole sampling session, the values of $\mathrm{BOD}_{7}$ and $\mathrm{COD}_{\mathrm{Cr}}$ in the reedbed were below the standard values, and maximum values were observed to be 9.7 and $99 \mathrm{mg} \mathrm{L}^{-1}$ respectively (Fig. 2). Because of the degradation of organic matter, however, one could expect some increase in these variables. The concentrations of $\mathrm{BOD}_{7}$ and $\mathrm{COD}_{\mathrm{Cr}}$ in WTP outflow and in the stabilization pond inflow and outflow were generally low and decreased towards the reedbed outflow. Relatively high $\mathrm{BOD}_{7}$ and $\mathrm{COD}$ values in the inflow to the reedbed may indicate the influence of sediments rich in carbon compounds accumulated here during the loading of the system by raw or unsatisfactory treated wastewater between the 1960s and the 1990s. Similar effects have been mentioned in analogous treatment wetland systems [9-11].
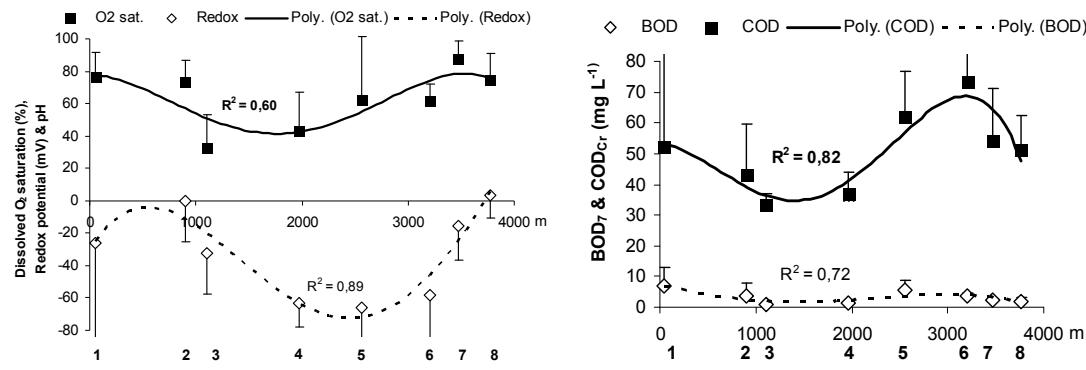

Figure 2: $\quad$ Variation in the average values of dissolved oxygen saturation (\%) and redox potential $(\mathrm{mV})$ (left), and levels of $\mathrm{BOD}_{7}$ and $\mathrm{COD}_{\mathrm{Cr}}$ (mg L ${ }^{-1}$; right) along the flow path of treated municipal wastewater from Lihula from April to October in 2007 and August in 2008. Error bars indicate standard deviation values. 1-8: water sampling sites (see Fig. 1). For significant trendlines $(\mathrm{p}<0.05)$, determination coefficients $\left(\mathrm{R}^{2}\right)$ are given.

The main form of mineral nitrogen is ammonia nitrogen, the concentration of which was higher in the WTP outflow and the inflow to the stabilization pond. This indicates that the WTP may have problems with mineralization of organic N and nitrification of $\mathrm{NH}_{4}$. Due to the suitable aerobic conditions (diffusion and photosynthesis) for the nitrification process in the stabilization pond and possible $\mathrm{N}$ uptake by plants in the inflow ditch, however, the average concentrations of ammonia $\mathrm{N}$ and total $\mathrm{N}$ decreased significantly from WTP outflow to reedbed outflow (from 6.8 and 9 to 0.2 and $1.2 \mathrm{mg} \mathrm{L}^{-1}$ respectively; Fig. 3). The average nitrate and nitrite $\mathrm{N}$ levels were low (from $0-0.15$ and 0.05 to $0.8 \mathrm{mg} \mathrm{L}^{-1}$ ), but decreased along the flow. Somewhat higher $\mathrm{NO}_{3}-\mathrm{N}$ concentrations in the outflow from the stabilization pond and in the reedbed inflow (Fig. 3) indicate varying conditions of nitrification and denitrification that may be influenced by dissolution and differences in soil microbial activity between the vegetation 

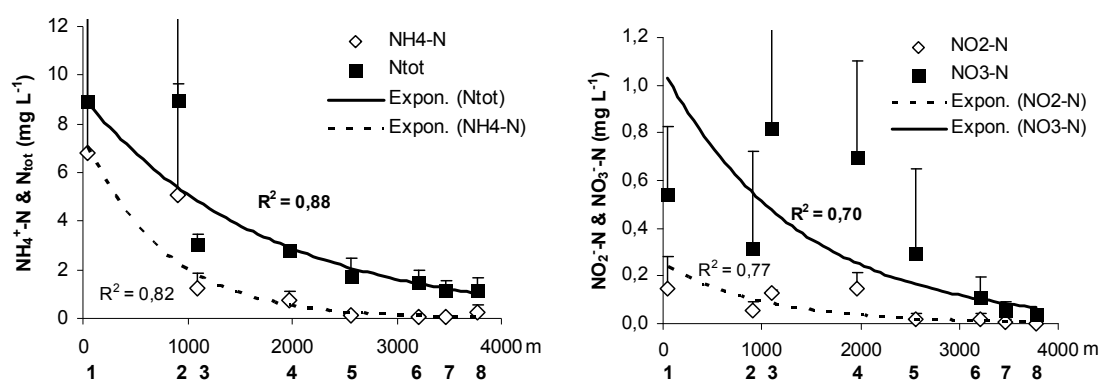

Figure 3: Variation of average values and standard deviations (error bars) of concentrations of nitrogen components along the flow path of treated municipal wastewater from Lihula from April to October 2007 and August 2008. For further explanation, see Figures 1 and 2 .
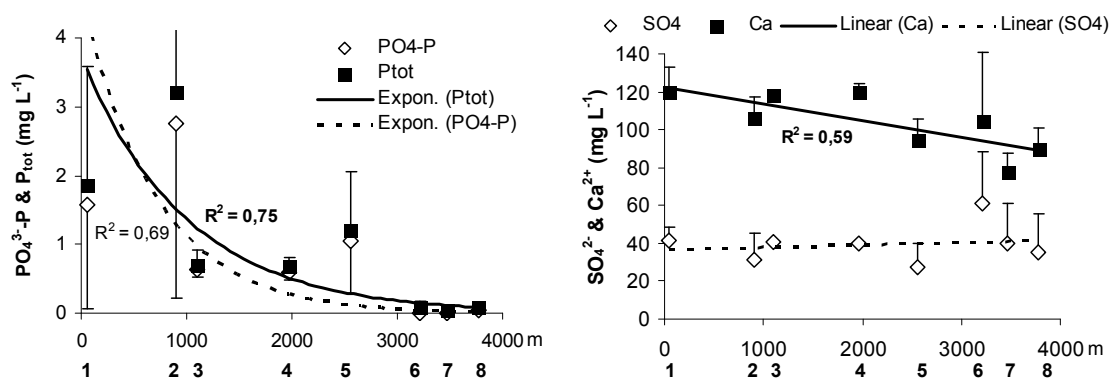

Figure 4: Variation of total phosphorus and $\mathrm{PO}_{4}{ }^{3-}-\mathrm{P}$ (left), and $\mathrm{Ca}^{2+}$ and $\mathrm{SO}_{4}{ }^{2-}$ along the flow path of treated municipal wastewater from Lihula from April to October 2007 and August 2008. For further explanation, see Figures 1 and 2.

patches. The main form of $\mathrm{N}$ in the reedbed was organic nitrogen $\left(\mathrm{N}_{\text {org }}=\mathrm{N}_{\text {tot }}\right.$ $\left.\mathrm{NH}_{4}-\mathrm{N}-\mathrm{NO}_{2}-\mathrm{N}-\mathrm{NO}_{3}-\mathrm{N}\right): 0.50-1.78 \mathrm{mg} \mathrm{N} \mathrm{L}^{-1}$, which is presumably caused by decay of plant litter.

The average concentration of both $\mathrm{PO}_{4}-\mathrm{P}$ and total $\mathrm{P}$ in water decreased rapidly toward the reedbed outflow (from 2.8 and 3.2 to 0.04 and $0.09 \mathrm{mg} \mathrm{L}^{-1}$, respectively; Fig. 4), whereas the initial concentrations of total P in June and August 2007 in the outflow of Lihula WTP and in the inflow to the stabilization pond extended the established quality standard (Table 1), and were 3.3 and 4.1 $\mathrm{mg} \mathrm{L}^{-1}$ and 4.9 and $9.0 \mathrm{mg} \mathrm{L}^{-1}$ respectively.

The concentration of $\mathrm{P}_{\text {tot }}$ in reedbed inflow in June $\left(2.4 \mathrm{mg} \mathrm{L}^{-1}\right)$ also exceeded the standard level. In August this value was lower $\left(1.6 \mathrm{mg} \mathrm{L}^{-1}\right)$ than the limit, but still high in the reedbed inflow. Total $\mathrm{P}$ concentrations were very low in the middle section and outflow of the reedbed and in the outflow ditch. Most likely phosphorus was removed from water by co-precipitation with $\mathrm{CaCO}_{3}[36,37]$. 
The decreasing trend of dissolved $\mathrm{Ca}$ along the flow path also supports this theory. The high $\mathrm{pH}$ value in this treatment system is due to the Ca-rich environment (Silurian marls and limestones and calcareous till as the main geological features; [26]), which is the main factor for $\mathrm{P}$ sedimentation in the system. Although several reports from $\mathrm{Ca}$ and Al-rich environments suggest that semi-natural treatment wetlands can remove $\mathrm{P}$ over a long period [6-8], it may become a problem in a few years, when $\mathrm{P}$ in the wetland soil returns to the water if the overloading continues [38].

There was a slight increase in $\mathrm{pH}$ values in the reedbed, from 7.2 - 8.8. This increase may come from the fact that in open water zones within wetlands, which can develop high levels of algal activity and in turn create a higher $\mathrm{pH}$ value [39]. Relatively high sulphate values (13-81.5 $\left.\mathrm{mg} \mathrm{SO}_{4} \mathrm{~L}^{-1}\right)$ in the reedbed may be caused by temporarily anaerobic conditions in the reedbed soil (Fig. 4; see also [40]).
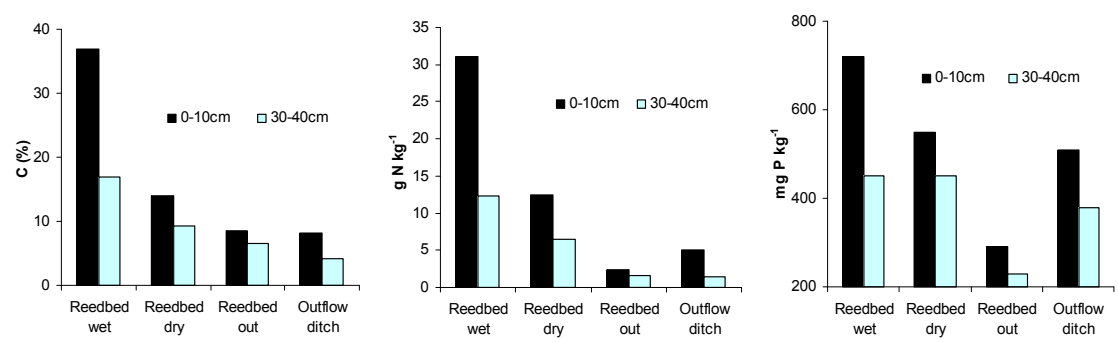

Figure 5: Average soil carbon, nitrogen and phosphorus concentrations in the treatment reedbed formed on Calcaric and Mollic Gleysols.

\subsection{Carbon, nitrogen, and phosphorus pattern of soils}

The carbon, nitrogen, and phosphorus concentration in soils showed higher values than the average for Calcaric and Mollic Gleysols in grasslands and coastal meadows in Estonia (8-10\% C, 2-5 $\mathrm{g} \mathrm{N} \mathrm{kg}^{-1}$, and 0.2-0.4 $\mathrm{g} \mathrm{P} \mathrm{kg}^{-1}$; [29, 41]). The soil pattern also demonstrates the long-term effect of wastewater loading to the reedbed: the $C, N$, and $P$ concentrations in both topsoil $(0-10 \mathrm{~cm})$ and at a depth of $30-40 \mathrm{~cm}$ decreased from the reedbed inflow towards the outflow, ranging from 37 to $4.2 \% \mathrm{C}$, from 31 to $1.4 \mathrm{~g} \mathrm{~N} \mathrm{~kg}^{-1}$, and from 720 to 230 mg $\mathrm{P} \mathrm{kg}^{-1}$ (Fig. 5).

\subsection{Emissions of $\mathrm{CO}_{2}, \mathrm{CH}_{4}, \mathrm{~N}_{2} \mathrm{O}$ and $\mathrm{N}_{2}$ in the reedbed}

\subsection{1 $\mathrm{CO}_{2}$}

The average $\mathrm{CO}_{2}$ emission from the reedbed varied from 14.3 to $334 \mathrm{mg} \mathrm{CO}-\mathrm{C}$ $\mathrm{m}^{-2} \mathrm{~h}^{-1}$. The highest $\mathrm{CO}_{2}$ emission rates were registered in June in the wet part and in the outflow part of the reedbed (Fig. 6). These values are significantly higher than those observed for boreal natural ombrotropic and transitional bogs in Fennoscandia (from -385 to $10.5 \mathrm{mg} \mathrm{CO}_{2}-\mathrm{C} \mathrm{m}^{-2} \mathrm{~h}^{-1}$; [42-45]), at the same level as emission values from boreal drained bogs (58.6-315 $\mathrm{mg} \mathrm{CO}_{2}-\mathrm{C} \mathrm{m}^{-2} \mathrm{~h}^{-1}$ ), 
and somewhat lower than those registered from boreal drained fens (120-744 $\mathrm{mg}$ $\mathrm{CO}_{2}-\mathrm{C} \mathrm{m}^{-2} \mathrm{~h}^{-1}$; [43, 46, 47]).

Comparatively high $\mathrm{CO}_{2}$ emission values were also registered in boreal organic agricultural soils in Finland (from 45 to $95 \mathrm{CO}_{2}-\mathrm{C} \mathrm{m}^{-2} \mathrm{~h}^{-1}$ in a grassland and arable land respectively; [48]), in a drained grassland on peatland soil in the Netherlands (167-250 mg $\mathrm{CO}_{2}-\mathrm{C} \mathrm{m}^{-2} \mathrm{~h}^{-1}$; [49]) and in a drained boreal spruce forest (533-611 $\mathrm{mg} \mathrm{CO}_{2}-\mathrm{C} \mathrm{m}^{-2} \mathrm{~h}^{-1}$; [50]).

The variation of the $\mathrm{CO}_{2}$ flux rate from the forest was $19.7-234 \mathrm{mg} \mathrm{CO}-\mathrm{C}$ $\mathrm{m}^{-2} \mathrm{~h}^{-1}$ and from the grassland $11.4-81.8 \mathrm{mg} \mathrm{CO}_{2}-\mathrm{C} \mathrm{m}^{-2} \mathrm{~h}^{-1}$ (Fig. 6).

\subsection{2 $\mathrm{CH}_{4}$}

The reedbed only emitted relatively small amounts of methane, but spatial and temporal variability was high. The average $\mathrm{CH}_{4}$ emission varied from 10.5 to $16397 \mu \mathrm{g} \mathrm{CH}_{4} \mathrm{~m}^{-2} \mathrm{~h}^{-1}$ from April to August (Fig. 6).
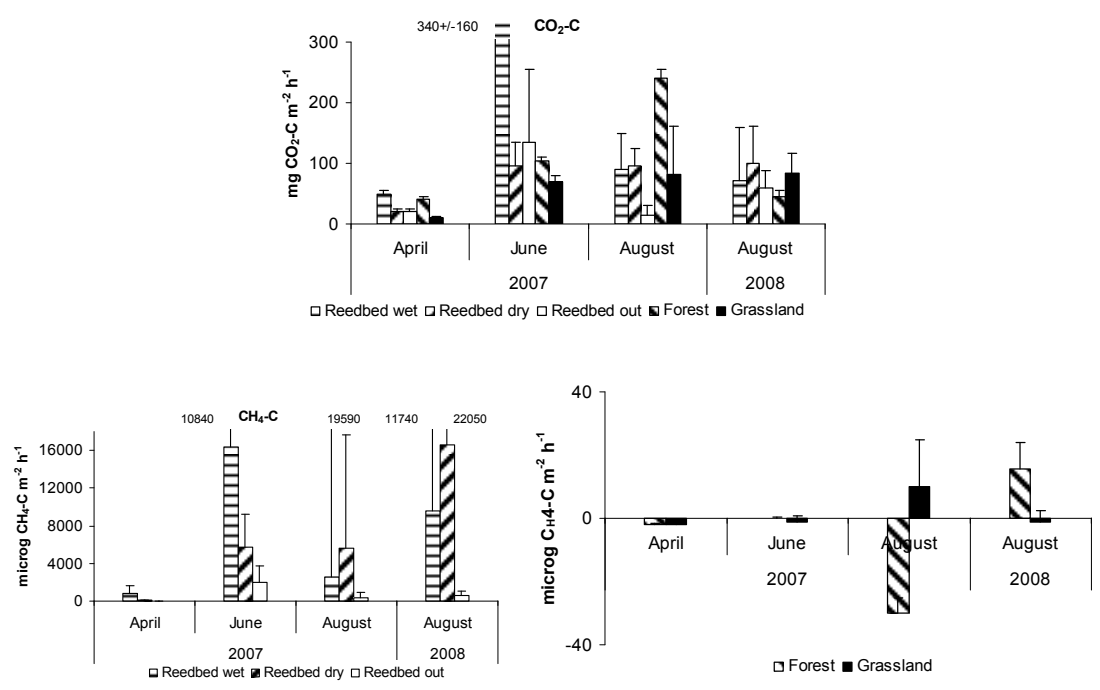

Figure 6: Average emission rates (standard deviation is indicated with error bars) of $\mathrm{CO}_{2}$ and $\mathrm{CH}_{4}$ from the reedbed, forest and grassland of the Lihula-Matsalu study area.

This variability is explained by the differences in temperature and changes in the water table (in April 0-10 cm above the soil surface and in June and August $0-10 \mathrm{~cm}$ below the soil surface). The decrease of the water table in the reedbed during summer increased methane emission in both wet and dry reedbeds, but decreased in the outflow of the reedbed. Flooding can reduce methane emission, probably by blocking the primary sites of methane release in the lower part of the reed plant stems [51]. The $\mathrm{CH}_{4}$ fluxes from forest (from -29.0 to $-0.8 \mu \mathrm{g} \mathrm{CH}_{4} \mathrm{~m}^{-2}$ $\mathrm{h}^{-1}$ ) and grassland (from -1.4 to $8.5 \mu \mathrm{g} \mathrm{CH}_{4} \mathrm{~m}^{-2} \mathrm{~h}^{-1}$ ) were significantly lower than from the reedbed (Fig. 6). This is clearly due to the impact of the drainage ditch. 
The $\mathrm{CH}_{4}-\mathrm{C}$ fluxes measured in the reedbed were in the same range as values gathered in pristine boreal bogs and fens (23-4623 $\mu \mathrm{g} \mathrm{CH}_{4} \mathrm{~m}^{-2} \mathrm{~h}^{-1}$; [47]), higher than values from drained boreal wetlands (from -83 to $570 \mu \mathrm{g} \mathrm{CH}_{4} \mathrm{~m}^{-2} \mathrm{~h}^{-1}$; $[46,47])$, and significantly lower than those registered in wastewater treatment wetlands $\left(27600-528000 \mu \mathrm{g} \mathrm{CH}_{4} \mathrm{~m}^{-2} \mathrm{~h}^{-1}\right.$; [16, 52]). Pools in raised bogs can show extremely high $\mathrm{CH}_{4}-\mathrm{C}$ emission values in summer (up to $131875 \mu \mathrm{g} \mathrm{CH}_{4}$ $\mathrm{m}^{-2} \mathrm{~h}^{-1}$; [53]). Also, Phragmites stands in boreal lakes $\left(85900 \mu \mathrm{g} \mathrm{CH}_{4} \mathrm{~m}^{-2} \mathrm{~h}^{-1}\right.$; [54]) and on Mollic Gleysols (up to $25432 \mu \mathrm{g} \mathrm{CH}_{4} \mathrm{~m}^{-2} \mathrm{~h}^{-1}$; [55]), rewetted fens (up to $9000 \mu \mathrm{g} \mathrm{CH}_{4} \mathrm{~m}^{-2} \mathrm{~h}^{-1}$; [32]) and small marshes within the agricultural landscape (up to $11575 \mu \mathrm{g} \mathrm{CH}_{4} \mathrm{~m}^{-2} \mathrm{~h}^{-1}$; [56]) can show high $\mathrm{CH}_{4}-\mathrm{C}$ emission values, whereas drained marshes converted to agricultural fields demonstrate significant $\mathrm{CH}_{4}$ uptake (up to $120 \mu \mathrm{g} \mathrm{CH}_{4} \mathrm{~m}^{-2} \mathrm{~h}^{-1}$; [57]). Except for some riparian alder forests [58], boreal and temperate forests oxidize $\mathrm{CH}_{4}$ [59] even when treated with sludge [60].

Pulsing hydrology can significantly influence $\mathrm{CH}_{4}$ fluxes, in most cases lowering emissions [61].

In August, during the maximal plant growth in reedbed, the $\mathrm{CH}_{4}-\mathrm{C}$ emissions were possibly underestimated because the reed plants might mediate methane fluxes [61-63].

\subsection{3 $\mathrm{N}_{2} \mathrm{O}$ and $\mathrm{N}_{2}$}

The average $\mathrm{N}_{2}$ and $\mathrm{N}_{2} \mathrm{O}$ fluxes from the reedbed varied from 7.1 to $16.1 \mathrm{mg} \mathrm{N}_{2}$ $\mathrm{m}^{-2} \mathrm{~h}^{-1}$ and from -5.0 to $3.7 \mu \mathrm{g} \mathrm{N} \mathrm{N}_{2} \mathrm{O} \mathrm{m} \mathrm{h}^{-1}$ respectively (Fig. 7). The highest values of $\mathrm{N}_{2}, 19.8 \mathrm{~g} \mathrm{~N}_{2} \mathrm{~m}^{-2} \mathrm{~h}^{-1}$ and $\mathrm{N}_{2} \mathrm{O} 19.0 \mu \mathrm{g} \mathrm{N}_{2} \mathrm{O} \mathrm{m}^{-2} \mathrm{~h}^{-1}$, were registered in April in the forest. In the grassland, $\mathrm{N}_{2}$ and $\mathrm{N}_{2} \mathrm{O}$ emission rates were relatively low, $6.8-7.4 \mathrm{mg} \mathrm{N}_{2} \mathrm{~m}^{-2} \mathrm{~h}^{-1}$ and $0.1-0.6 \mu \mathrm{g} \mathrm{N}_{2} \mathrm{O} \mathrm{m}^{-2} \mathrm{~h}^{-1}$ respectively. Higher nitrous oxide emission values from the forest are probably influenced by the nearby drainage ditch. It is known that the change in wetland water regime significantly influences $\mathrm{GHG}$ fluxes, decreasing the $\mathrm{CH}_{4}$ emission [64] and increasing $\mathrm{N}_{2} \mathrm{O}[46,65]$ and $\mathrm{CO}_{2}$ emissions $[49,66]$. In most cases, pulsing water regime increases $\mathrm{N}_{2} \mathrm{O}$ emissions [67], although there are also contradictory results [68]. Some investigations show that Phragmites plants can mediate $\mathrm{N}_{2} \mathrm{O}$ emission [69], whereas other have not found any relationship between the reed plant biomass and $\mathrm{N}_{2} \mathrm{O}$ emission [70].

There are not many literature sources on $\mathrm{N}_{2}$ emissions from wetland or forest ecosystems. Teiter and Mander [19] and Mander et al. [18, 58] demonstrated high $\mathrm{N}_{2}$ emission rates (up to $1200 \mathrm{~kg} \mathrm{~N}_{2}-\mathrm{N} \mathrm{ha}^{-1} \mathrm{yr}^{-1}$ ) and high $\mathrm{N}_{2}: \mathrm{N}_{2} \mathrm{O}$ (up to 2000) ratios in both HSSF CW and riparian alder forests, which indicates that in these ecosystems the denitrification process lasts to the very end, and not much $\mathrm{N}_{2} \mathrm{O}$ is formed. Data on dinitrogen emission and the $\mathrm{N}_{2}: \mathrm{N}_{2} \mathrm{O}$ ratio gathered in this study are comparable with those presented in the literature [18, 19, 58]. Surprisingly, other forest ecosystems studied for dinitrogen fluxes show very low $\mathrm{N}_{2}$ emission values and very low $\mathrm{N}_{2}: \mathrm{N}_{2} \mathrm{O}$ ratios [71].

Values of $\mathrm{N}_{2} \mathrm{O}-\mathrm{N}$ emission from our study are significantly lower than the values observed in various CWs for wastewater treatment (up to 17,000 $\mu \mathrm{g} \mathrm{N}_{2} \mathrm{O}$ $\left.\mathrm{m}^{-2} \mathrm{~h}^{-1} ;[13,14,16,17,72]\right)$, lower than those reported from drained boreal 
peatlands (2-331 $\mu \mathrm{g} \mathrm{N}_{2} \mathrm{O} \mathrm{m}^{-2} \mathrm{~h}^{-1}$; [47]) and comparable with flux values reported on pristine boreal peatland ecosystems (1.14-27.4 $\mu \mathrm{g} \mathrm{N}_{2} \mathrm{O} \mathrm{m}^{-2} \mathrm{~h}^{-1}$; [42, 65]), Antarctic tundra soils $\left(0.81-1.36 \mu \mathrm{g} \mathrm{N} \mathrm{N}_{2} \mathrm{O} \mathrm{m} \mathrm{h}^{-1} ;\right.$ [73]), temperate meadow grasslands $\left(7.9-41 \mu \mathrm{g} \mathrm{N} \mathrm{O} \mathrm{m}^{-2} \mathrm{~h}^{-1}\right.$; [74]) and semi-natural grasslands $(16.9-46 \mu \mathrm{g}$ $\left.\mathrm{N}_{2} \mathrm{O} \mathrm{m} \mathrm{m}^{-2} \mathrm{~h}^{-1} ;[75]\right)$.
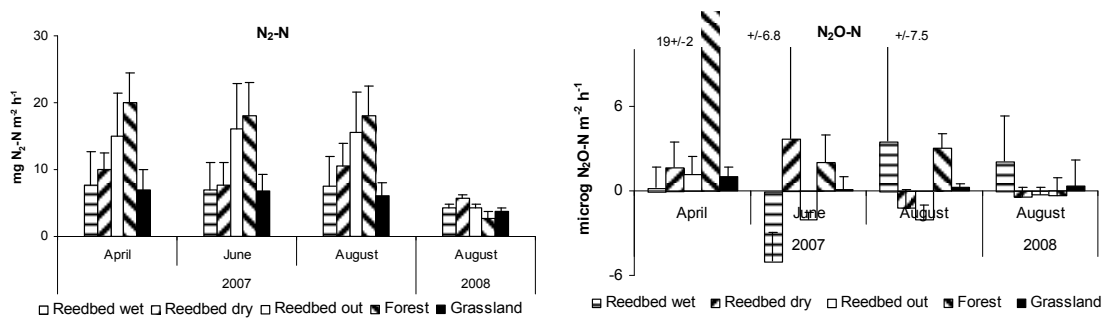

Figure 7: Average emission rates (standard deviation is marked as error bars) of $\mathrm{N}_{2}$ and $\mathrm{N}_{2} \mathrm{O}$, from the reedbed, forest and grassland of the Lihula-Matsalu study area.

Grasslands [76] and wetlands with altered water regime [77] show higher $\mathrm{N}_{2} \mathrm{O}-\mathrm{N}$ emission (up to $184 \mu \mathrm{g} \mathrm{N}_{2} \mathrm{O} \mathrm{m}^{-2} \mathrm{~h}^{-1}$ ). Forests emit low amounts of nitrous oxide (from low consumption up to $35 \mu \mathrm{g} \mathrm{N} \mathrm{N}_{2} \mathrm{O} \mathrm{m}^{-2} \mathrm{~h}^{-1}$; [78, 79]), whereas deciduous forests tend to emit more than coniferous forests [80].

Several studies suggest that a large amount of $\mathrm{N}_{2} \mathrm{O}$ can be emitted from various soils, even at temperatures below $0^{\circ} \mathrm{C}[81,82]$. The main mechanism for $\mathrm{N}_{2} \mathrm{O}$ in frozen soil is denitrification [83], whereas $\mathrm{N}_{2} \mathrm{O}$ can be produced in unfrozen water films in an anaerobic soil matrix in frozen soil [84]. Emission of $\mathrm{N}_{2} \mathrm{O}$ in winter may account for more than half of the annual emission in boreal and temperate areas $[85,66]$. Freezing and thawing cycles significantly increase $\mathrm{N}_{2} \mathrm{O}$ emissions [87, 88]. Grasslands in intensive agricultural use demonstrate high $\mathrm{N}_{2} \mathrm{O}$ emissions, especially on organic drained soils (up to $7.1 \mathrm{~kg} \mathrm{~N} \mathrm{~N}_{2} \mathrm{O}-\mathrm{N}$ $\mathrm{ha}^{-1} \mathrm{yr}^{-1}$; [48]), in pastures (up to $24.5 \mathrm{~kg} \mathrm{~N}_{2} \mathrm{O}-\mathrm{N} \mathrm{ha}{ }^{-1} \mathrm{yr}^{-1}$; [89]), and after intensive fertilization (up to $15.9 \mathrm{~kg} \mathrm{~N}_{2} \mathrm{O}-\mathrm{N} \mathrm{ha}^{-1} \mathrm{yr}^{-1}$; [90]).

Investigations have found that the constantly high water table in soil and substrates is an important precondition for $\mathrm{N}_{2}$ emission [91, 92].

\subsection{Approximation of gas emission values for yearly base}

According to the temporal pattern of GHGs found in constructed wetlands [19], we estimated the annual average emission values of the studied gases in the Lihula-Matsalu treatment reedbed (Table 2). Our short-term investigation characterizes the average vegetation period pattern of GHG emissions [17]. Concerning the $\mathrm{CH}_{4}$ and $\mathrm{N}_{2}$ fluxes, we multiplied the calculated vegetation period values by the coefficient 0.5 [17], whereas $\mathrm{N}_{2} \mathrm{O}$ emissions are assumed to be at about the same level in both cold and warm seasons [93].

In our study, $\mathrm{CO}_{2}$ emission is not connected with fluxes related to plant photosynthesis. Therefore, the results cannot be considered losses to the 
atmosphere. Although the $\mathrm{CO}_{2}$ emission is known to increase during the freezing-thawing cycles, as is the case with $\mathrm{N}_{2} \mathrm{O}-\mathrm{N}$ emission [94], we assume that there is no significant flux of $\mathrm{CO}_{2}$ in winter, and that the non-considered $\mathrm{C}$ fixation in photosynthesis can compensate about $75 \%$ of emission. Therefore, for approximation we multiplied the calculated vegetation period values of $\mathrm{CO}_{2}-\mathrm{C}$ emissions with the coefficient 0.25 (Table 2). However, considering analogous studies on gaseous carbon fluxes from constructed wetlands [18], one can assume that the fixation of atmospheric $\mathrm{CO}_{2}$ to plant tissues via photosynthesis and binding in soil microorganisms could compensate emissions in the vegetation period. In a horizontal subsurface flow (HSSF) constructed wetland (CW), the annual sequestration of $\mathrm{C}$ in different years was 484 and $649 \mathrm{~kg} \mathrm{C}$ per $312,5 \mathrm{~m}^{2}$ wetland area, while $\mathrm{CO}_{2}-\mathrm{C}$ emissions were 120 and $230 \mathrm{~kg} \mathrm{C}$ per wetland area [18].

Table 2: Estimated annual average emission rates of carbon dioxide, methane, nitrous oxide and dinitrogen from the reedbed $\left(\mathrm{kg} \mathrm{ha}^{-1}\right.$ $\left.\mathrm{yr}^{-1}\right)$.

\begin{tabular}{lrrrr}
\hline & $\mathbf{C O}_{\mathbf{2}}-\mathbf{C}$ & $\mathbf{C H}_{\mathbf{4}}-\mathbf{C}$ & $\mathbf{N}_{\mathbf{2}} \mathbf{O}-\mathbf{N}$ & $\mathbf{N}_{\mathbf{2}}$ \\
\hline Reedbed wet & 3020 & 0.30 & 0.02 & 290 \\
Reedbed dry & 1700 & 0.30 & 0.08 & 370 \\
Reedbed out & 1250 & 0.03 & -0.07 & 560 \\
Forest & 2360 & 0 & 0.52 & 640 \\
Grassland & 1350 & 0 & 0.04 & 260 \\
\hline
\end{tabular}

The $\mathrm{C}$ balance in a restored natural peatland in the Netherlands showed quite analogous results to the HSSF CW: the annual ecosystem exchange of $\mathrm{CO}_{2}$ for the years 2002-2004 varied from $-232+/-57$ to $-446+/-83 \mathrm{~g} \mathrm{C} \mathrm{m}^{-2} \mathrm{yr}^{-1}$, whereas the variation of ecosystem respiration was from $866+/-666$ to $924+/-711 \mathrm{~g} \mathrm{C} \mathrm{m}^{-2}$ $\mathrm{yr}^{-1}$ [95]. However, a significantly lower density of Phragmites stands and phytomass value in Lihula-Matsalu reedbed (unpublished data by M. Maddison) allows one to estimate that the $\mathrm{C}$ fixation in plants is 3-4 times lower than in the above-mentioned HSSF CW. The wet inflow part of the reedbed is probably a source of $\mathrm{CO}_{2}-\mathrm{C}$, whereas in the outflow part and drier areas, emission and uptake might be balanced (see Table 2). Similarly, investigations in afforested boreal organic (former) agricultural soils show that the $\mathrm{C}$ accumulation in the developing tree stands can partly compensate the relatively high $\mathrm{C}$ loss from the soil [96].

\section{Conclusions}

Our data suggest that the reedbed studied can effectively polish the sometimes unsatisfactory treated wastewater effluent. The values of $\mathrm{BOD}_{7}$ and $\mathrm{COD}$, as well as all forms of nitrogen in the treated water were low $\left(<8\right.$ and $<70 \mathrm{mg} \mathrm{L}^{-1}$ of BOD and COD respectively, $<10,<8,<1.0$, and $<0.2 \mathrm{mg} \mathrm{L}^{-1}$ for total $\mathrm{N}, \mathrm{NH}_{4}-\mathrm{N}$, $\mathrm{NO}_{3}-\mathrm{N}$, and $\mathrm{NO}_{2}-\mathrm{N}$, correspondingly), whereas the average concentrations of all nitrogen forms significantly decreased from WTP outflow to reedbed outflow. 
The concentration of phosphorus in the effluent of the wastewater treatment plant, which appears to be higher than established for sensitive receiving water bodies standards $\left(1 \mathrm{mg} \mathrm{P} \mathrm{L}^{-1}\right)$, decreased rapidly toward the reedbed outflow. Carich soils will presumably guarantee $\mathrm{P}$ removal for a longer period.

Accumulation of $\mathrm{C}, \mathrm{N}$ and $\mathrm{P}$ in soil (concentration of all components in both topsoil and to a depth of $30-40 \mathrm{~cm}$ decreased from the reedbed inflow towards the outflow), increasing $\mathrm{COD}$ values and lowering redox potential/dissolved $\mathrm{O}_{2}$ values in water, and higher $\mathrm{CH}_{4}$ and $\mathrm{CO}_{2}$ emission rates in the inflow site of reedbed demonstrate a long-term impact of sewage loading.

The average $\mathrm{N}_{2}$ and $\mathrm{N}_{2} \mathrm{O}$ fluxes from the reedbed varied from 4.0 to $16.1 \mathrm{mg}$ $\mathrm{N}_{2} \mathrm{~m}^{-2} \mathrm{~h}^{-1}$ and from -5.0 to $3.7 \mu \mathrm{g} \mathrm{N}_{2} \mathrm{O} \mathrm{m}^{-2} \mathrm{~h}^{-1}$ respectively. Although the spatialtemporal variation of methane emission was great $\left(10.5-16397 \mu \mathrm{g} \mathrm{CH}_{4} \mathrm{~m}^{-2} \mathrm{~h}^{-1}\right)$, showing higher values in the inflow part in June, the average emission value of methane is relatively low and comparable to natural wetland areas. Unexpectedly, $\mathrm{N}_{2} \mathrm{O}$ fluxes from the reedbed were even lower. It coincided closely with relatively high $\mathrm{N}_{2}$ emission values. This demonstrates that the denitrification process in this wetland ecosystem can be completed until the last product, which is least harmful to the atmosphere.

The average $\mathrm{CO}_{2}$ emission from the reedbed varied from 14.3 to $334 \mathrm{mg} \mathrm{CO}_{2}$ $\mathrm{C} \mathrm{m}^{-2} \mathrm{~h}^{-1}$, being somewhat higher in the inflow area. Our rough calculations based on published materials on analogous systems make it possible to estimate that the fixation of atmospheric $\mathrm{CO}_{2}$ to plant tissues via photosynthesis and binding in soil microorganisms can compensate emissions in the vegetation period.

Further management of the stabilization pond (removal of the sediment), replacement of leaking sewage pipes and the sustainable harvesting of reed in the reedbed for construction and energy production are preconditions for the sustainable management of the Lihula-Matsalu reedbed.

\section{Acknowledgements}

This study was supported by the INTERREG IIIA project "Reed Strategy in Finland and Estonia" (2005-2007), by Estonian Science Foundation Grant No. 7527 and Target Funding Project No. SF0180127s08 of the Ministry of Education and Science of Estonia.

\section{References}

[1] Jenssen, P.D., Mæhlum, T. \& Krogstad, T., Potential use of constructed wetlands for wastewater treatment in northern environments. Water Science and Technology, 28, pp. 149-157, 1993.

[2] Kadlec, R.H. \& Knight, R.L. Treatment Wetlands. CRC Press/Lewis Publishers: New York, 893 pp., 1996.

[3] Vymazal, J., Brix, H., Cooper, P.F., Green, M.B. \& Haberl R. (eds.), Constructed Wetlands for Wastewater Treatment in Europe. Backhuys Publishers, Leiden, The Netherlands, 366 pp., 1998. 
[4] Kadlec, R.H. \& Wallace, S.D., Treatment Wetlands. $2^{\text {nd }}$ Edition. CRC Press, Boca Raton, 952 pp., 2008.

[5] Velty, S., Behrendt, A. \& Zeitz, J., Natural wetland restoration and the use of municipal wastewater. Journal of Plant Nutrition and Soil Science, 169(5), pp. 642-650, 2006.

[6] Dierberg, F.E. \& Brezonik, P.L., Nitrogen and phosphorus mass balances in natural and sewage-enriched cypress domes. Journal of Applied Ecology, 20(1), pp. 323-337, 1983.

[7] DeBusk, W.F. \& Reddy, K.R., 79-86, 1987.

[8] Cooke, J.G. Phosphorus removal processes in a wetland after a decade of receiving a sewage effluent. Journal of Environmental Quality, 21, pp. 733739, 1992.

[9] Nõges, P. \& Järvet, A., Response of a natural river valley wetland to supplementary runoff and pollutant load from urban wastewater discharge. In: Mander, Ü. \& Jenssen, P.D. (eds.) Natural Wetlands for Wastewater Treatment in Cold Climates. Advances in Ecological Sciences Vol. 12. WIT Press, Southampton, Boston, pp. 139-158, 2002.

[10] Maddison, M., Soosaar, K., Lõhmus, K. \& Mander, Ü., Cattail population in wastewater treatment wetlands in Estonia: biomass production, retention of nutrients and heavy metals in phytomass. Journal of Environment Science and Health, Part A 40(6-7), pp. 1157-1166, 2004.

[11] Öövel, M., Tarajev, R., Kull, A. \& Mander, Ü. Tertiary treatment of municipal wastewater in a floodplain peatland. In: De Conçeicao Cunha, M. \& Brebbia, C.A. (eds.) Water Resources Management III. WIT Transactions on Ecology and the Environment Vol. 80, WIT Press, Southampton, Boston, pp. 433-444, 2005.

[12] Brix, H., Sorrell, B.K. \& Lorenzen, B., Are Phragmites-dominated wetlands a net source or a net sink of greenhouse gases? Aquatic Botany, 69, pp. 313-324, 2001.

[13] Fey, A., Benckiser, G. \& Ottow, J.C.G., Emissions of nitrous oxide from a constructed wetland using a groundfilter and macrophytes in waste-water purification of a dairy farm. Biology and Fertility of Soils, 29, pp. 354-359, 1999.

[14] Johansson, A.E., Kasimir Klemedtsson, Å., Klemedtsson, L. \& Svensson, B.H., Nitrous oxide exchanges with the atmosphere of a constructed wetland treating wastewater. Tellus B, 55, pp. 737-750, 2002.

[15] Johansson, A.E., Gustavsson, A.-M. Öquist, M.G. \& Svensson, B.H., Methane emissions from a constructed wetland treating wastewater seasonal and spatial distribution and dependence on edaphic factors. Water Research, 38, pp. 3960-3970. 2004.

[16] Tai, P.-D., Li, P.-J., Sun, T.-H., He, Y.-W., Zhou, Q.-X., Gong, Z.-Q., Mizuochi, M. \& Inamori, Y.H., Greenhouse gas emissions from a constructed wetland for municipal sewage treatment. Journal of Environmental Sciences 14(1), pp. 27-33, 2002.

[17] Mander, Ü., Kuusemets, V., Lõhmus, K., Mauring, T., Teiter, S. \& Augustin, J., Nitrous oxide, dinitrogen, and methane emission in a 
subsurface flow constructed wetland. Water Science and Technology, 48(5), pp. 135-142, 2003.

[18] Mander, Ü., Lõhmus, K., Teiter, S., Mauring, T., Nurk, K. \& Augustin J., Gaseous fluxes in the nitrogen and carbon budgets of subsurface flow constructed wetlands. Science of the Total Environment, 404, pp. 343-353, 2008a.

[19] Teiter, S. \& Mander Ü., Emission of $\mathrm{N}_{2} \mathrm{O}, \mathrm{N}_{2}, \mathrm{CH}_{4}$ and $\mathrm{CO}_{2}$ from constructed wetlands for wastewater treatment and from riparian buffer zones. Ecological Engineering, 25(5), pp. 528-541, 2005.

[20] Liikanen, A., Huttunen, J.T., Karjalainen, S.M., Heikkinen, K., Väisänen, T.S., Nykänen, H. \& Martikainen, P.J., Temporal and seasonal changes in greenhouse gas emissions from a constructed wetland purifying peat mining runoff waters. Ecological Engineering, 26, pp. 241-251, 2006.

[21] Picek, T., Čížková, H. \& Dušek, J., Greenhouse gas emissions from a constructed wetland- Plants as important sources of carbon. Ecological Engineering 31(2), pp. 98-106, 2007.

[22] Søvik, A.K., Augustin, J., Heikkinen, K., Huttunen, J.T., Necki, J.M., Karjalainen, S.M., Kløve, B., Liikanen, A., Mander, Ü., Puustinen, M., Teiter S. \& Wachniew, P., Emission of the greenhouse gases nitrous oxide and methane from constructed wetlands in Europe. Journal of Environmental Quality 35(6), pp. 2360-2373, 2006.

[23] Søvik, A.K. \& Kløve, B., Emission of $\mathrm{N}_{2} \mathrm{O}$ and $\mathrm{CH}_{4}$ from a constructed wetland in southeastern Norway. Science of the Total Environment 380, pp. 28-37, 2007.

[24] Wang, Y., Inamori, R., Kong, H., Xu, K., Inamori, Y., Kondo, T. \& Zhang, J., Nitrous oxide emission from polyculture constructed wetlands: Effect of plant species. Environmental Pollution 152, pp. 351-360, 2008.

[25] Eesti Veevärk Konsultatsioon AS. Development plan of water supply and sewage system of Lihula Parish. Tallinn, 102 pp., 2003.

[26] Raukas, A., Quaternary sediments. In: Raukas, A. (ed.) Estonia Nature. Tallinn, Valgus, pp. 92-1188, 1995. (In Estonian).

[27] Kessel, H. \& Punning, J.-M. The Baltic Sea and its development. In: Raukas, A. (ed.) Estonia Nature. Tallinn, Valgus, pp. 219-228, 1995. (In Estonian).

[28] Soil Map of Estonia. 2008. http://xgis.maaamet.ee/xGIS/XGis (In Estonian)

[29] Kõlli, R., Classification problems of Estonian soils. In: Reintam, L. (ed.) Classification of Estonian Soils 198, Tartu, Estonian Agricultural University, pp. 9-23, 1998.

[30] APHA, 1989. Standard Methods for the Examination of Water and Wastewater. American Public Health Organisation, $17^{\text {th }}$ edition, Washington, DC.

[31] Loftfield, N., Flessa, H., Augustin, J. \& Beese, F., Automated gas chromatographic system for rapid analysis of the atmospheric trace gases methane, carbon dioxide, and nitrous oxide. Journal of Environmental Quality, 26(2), pp. 560-564, 1997. 
[32] Augustin, J., Merbach, W. \& Rogasik, J., Factors influencing nitrous oxide and methane emissions from minerotrophic fens in northeast Germany. Biology and Fertility of Soils 28(1), pp. 1-4, 1998.

[33] Butterbach-Bahl, K., Willibald, G. \& Papen, H., A new method for simultaneous measurements of $\mathrm{N}_{2}$ and $\mathrm{N}_{2} \mathrm{O}$ - emissions from intact soil cores. In: Van Cleemput, O., Haneklaus, S., Hofman, G., Schnug, E. \& Vermoesen, A. (eds.) Fertilization for Sustainable Plant Production and Soil Fertility. Proceedings of $11^{\text {th }}$ World Fertilizer Congress of CIEC, Vol. 2, pp. 618-624, 1997.

[34] Augustin, J., Münchmeyer, U. \& Russow, R., $\mathrm{N}_{2} \mathrm{O}$ and $\mathrm{N}_{2}$ fluxes from reflooded fen peatlands with and without wetland plants in lab model experiments. In: Mander, Ü. \& Jenssen, P.D. (eds.) Natural Wetlands for Wastewater Treatment in Cold Climates. Advances in Ecological Sciences 12, Southampton, Boston, pp. 127-137, 2002.

[35] Requirements for wastewater discharged into water bodies or into soil. Regulation No. 327 of 19 December 2003 of the Government of the Republic of Estonia, In: RT I 2003.83.565 Tallinn, Estonia, (State Gazette), 2003. (In Estonian).

[36] Anderson, C.J. \& Mitsch W.J., Sediment, carbon, and nutrient accumulation at two 1-year-old created riverine marshes. Wetlands, 26(3), pp. 779-792, 2006.

[37] Novak, J.M. \& Watts, D.W., Phosphorus sorption by sediments in a southeastern coastal plain in-stream wetland. Journal of Environmental Quality, 35, pp. 1975-1982, 2006.

[38] Vohla, C., Alas, R., Nurk, K., Baatz, S. \& Mander, Ü. Dynamics of phosphorus, nitrogen and carbon removal in a horizontal subsurface flow constructed wetland. Science of the Total Environment, 380(1-3), pp. 66-74, 2007.

[39] Koskiaho, J., Ekholm, P., Räty, M., Riihimäki, J. \& Puustinen, M., Retaining agricultural nutrients in constructed wetlands - experiences under boreal conditions. Ecological Indicators, 20(1), pp. 89-103, 2003.

[40] Lamers, L.P.M., Ten Dolle, G.E., Van den Berg, S.T.G., Van Delft, S.P.J. \& Roelofs, J.G.M., Differential responses of freshwater wetland soils to sulphate pollution. Biogeochemistry, 55(1), pp. 87-102, 2001.

[41] Reintam, L., Genesis, diagnostics and classification of soils. In: Reintam, L. (ed.) Classification of Estonian Soils 198.Tartu, Estonian Agricultural University, pp. 24-36, 1998.

[42] Minkkinen, K., Korhonen, R., Savolainen, I. \& Laine J., Carbon balance and radiative forcing of Finnish peatlands 1900-2100 - the impact of forestry drainage. Global Change Biology, 8, pp. 785-799, 2002.

[43] Minkkinen, K., Penttilä, T. \& Laine, J., Tree stand volume as a scalar for methane fluxes in forestry-drained peatlands in Finland. Boreal Environment Research, 12, pp. 127-132, 2007.

[44] Alm, J., Shurpali, N.J., Minkkinen, K., Aro, L., Hytönen, J., Laurila, T., Lohila, A., Maljanen, M., Martikainen, P.J., Mäkiranta, P., Penttilä, T., Saarnio, S., Silvan, N., Tuittila, E.-S. \& Laine, J., Emission factors and 
their uncertainty for the exchange of $\mathrm{CO}_{2}, \mathrm{CH}_{4}$ and $\mathrm{N}_{2} \mathrm{O}$ in Finnish managed peatlands. Boreal Environment Research, 12, pp. 191-209, 2007.

[45] Saarnio, S., Morero, M., Shurpali, N.J., Tuittila, E.-S., Mäkilä, M. \& Alm, J., Annual $\mathrm{CO}_{2}$ and $\mathrm{CH}_{4}$ fluxes of pristine boreal mires as a background for the lifecycle analyses of peat energy. Boreal Environment Research, 12, pp. 101-113, 2007.

[46] Martikainen, P.J., Nykanen, H., Crill, P. \& Silvola J., Effect of a lowered water-table on nitrous oxide fluxes from northern peatlands. Nature, 366, pp. 51-53, 1993.

[47] Salm, J.-O., Kimmel, K. \& Mander, Ü., Changes in the ecosystem services of mires in Estonia, estimated on the basis of $\mathrm{CO}_{2}, \mathrm{CH}_{4}$ and $\mathrm{N}_{2} \mathrm{O}$ emissions. Wetlands, 2009. (In press).

[48] Maljanen, M., Komulainen, V.-M., Hytönen, J., Martikainen, P.J. \& Laine, J., Carbon dioxide, nitrous oxide and methane dynamics in boreal organic agricultural soils with different soil characteristics. Soil Biology and Biochemistry, 36, pp. 1801-1808, 2004.

[49] Van den Pol-van Dasselaar, A., Corré, W.J., Priemé, A., Klemedtsson, Å.K., Weslien, P., Stein, A., Klemedtsson, L. \& Oenema, O., Spatial variability of methane, nitrous oxide, and carbon dioxide emissions from drained grasslands. Soil Science Society of America Journal, 62, pp. 810$817,1998$.

[50] Maljanen, M., Jokinen, H., Saari, A., Strömmer, R. \& Martikainen, P.J., Methane and nitrous oxide fluxes, and carbon dioxide production in boreal forest soil fertilized with wood ash and nitrogen. Soil Use and Management, 22, pp. 151-157, 2006.

[51] Van der Nat, F.J.W.A. \& Middelburg, J.J., Methane emission from tidal freshwater marshes. Biogeochemistry, 49(2), pp. 103-121, 2000.

[52] Tanner, C.C., Adams, D.D. \& Downes, M.T., Methane emissions from constructed wetlands treating agricultural wastewaters. Journal of Environmental Quality, 26(4), pp. 1056-62, 1997.

[53] Pelletier, L., Moore, T.R., Roulet, N.T., Garneau, M. \& Beaulieu-Audy, V., Methane fluxes from three peatlands in the La Grande Riviere watershed, James Bay lowland, Canada. Journal of Geophysical Research, 112, G01018, pp. 1-12, 2007.

[54] Käki, T., Ojala, A. \& Kankaala, P., Diel variation in methane emissions from stands of Phragmites australis (Cav.) Trin. ex Steud. and Typha latifolia L. in a boreal lake. Aquatic Botany, 71(4), pp. 259-271, 2001.

[55] Sommer, M., Fiedler, S., Glatzel, S. \& Kleber, M., First estimates of regional (Allgäu, Germany) and global $\mathrm{CH}_{4}$ fluxes from wet colluvial margins of closed depressions in glacial drift areas. Agriculture, Ecosystems and Environment, 103, pp. 251-257, 2004.

[56] Phillips, R. \& Beeri, O., The role of hydropedologic vegetation zones in greenhouse gas emissions for agricultural wetland landscapes. Catena, 72, pp. 386-394, 2008. 
[57] Ding, W., Cai, Z. \& Tsuruta, H., Cultivation, nitrogen fertilization, and setaside effects on methane uptake in a drained marsh in Northeast China. Global Change Biology, 10, pp. 1801-1809, 2004.

[58] Mander, Ü., Lõhmus, K., Teiter, S., Uri, V. \& Augustin J. Gaseous nitrogen and carbon fluxes in riparian alder stands. Boreal Environment Research, 13, pp. 231-241. 2008b.

[59] Dobbie, K.E., Smith, K.A., Priemé, A., Christensen, S., Degorska, A. \& Orlanski, P., Effect of land use on the rate of methane uptake by surface soils in Northern Europe. Atmospheric Environment, 30, pp. 1005-111, 1996.

[60] Ambus, P., Jensen, J.M., Priemé, A., Pillegaard, K. \& Kjøller, A., Assessment of $\mathrm{CH}_{4}$ and $\mathrm{N}_{2} \mathrm{O}$ fluxes in a Danish beech (Fagus sylvatica) forest and an adjacent $\mathrm{N}$-fertilised barley (Hordeum vulgare) field: effects of sewage sludge amendments. Nutrient Cycling in Agroecosystems, 60(13), pp. 15-21, 2001.

[61] Altor, A.E. \& Mitsch, J.W., Methane flux from created marshes: Effects of intermittent vs. continuous inundation and emergent macrophytes. Ecological Engineering, 28(3), pp. 224-234, 2006.

[62] Grünfeld, S. \& Brix, H., Methanogenesis and methane emissions: effects of water table, substrate type and presence of Phragmites australis. Aquatic Botany, 64(1), pp. 63-75, 1999.

[63] Duan, X.N., Wanga, X.K. \& Ouyang, Z.Y., Plant-mediated $\mathrm{CH}_{4}$ emission from a Phragmites-dominated wetland in an arid region, China. Journal of Freshwater Ecology, 21(1), pp. 139-145, 2006.

[64] Harris, R.C., Gorham, E., Sebacher, D.I., Bartlett, K.B. \& Flebbe, P.A., Methane flux from northern peatlands. Nature, 315, pp. 652-654, 1985.

[65] Yu, J., Liu, J., Wang, J., Sun, W., Patrick Jr., W.H. \& Meixner, F.X., Nitrous oxide emission from Deyeuxia angustifolia freshwater marsh in Northeast China. Environmental Management, 40, pp. 613-622, 2007.

[66] Kasimir-Klemedtsson, Å., Klemedtsson, L., Berglund, K., Martikainen, P., Silvola, J. \& Oenema, O., Greenhouse gas emissions from farmed organic soils: a review. Soil Use and Management, 13, pp. 245-250, 1997.

[67] Flessa, H., Wild, U. \& Pfadenhauer, J., Nitrous oxide and methane fluxes from organic soils under agriculture. European Journal of Soil Science, 49, pp. 327-335, 1998.

[68] Hernandez, M.E. \& Mitsch, W.J., Influence of hydrologic pulses, flooding frequency, and vegetation on nitrous oxide emissions from created riparian marshes. Wetlands, 26(3), pp. 862-877, 2006.

[69] Rückauf, U., Augustin, J., Russow, R. \& Merbach, W., Nitrate removal from drained and reflooded fen soils affected by soil $\mathrm{N}$ transformation processes and plant uptake. Soil Biology and Biochemistry, 36, pp. 77-90, 2004.

[70] Cheng, X., Peng, R., Chen, J., Luo, Y., Zhang, Q., An, S., Chen, J. \& Li, B., $\mathrm{CH}_{4}$ and $\mathrm{N}_{2} \mathrm{O}$ emissions from Spartina alterniflora and Phragmites australis in experimental mesocosms. Chemosphere, 68, pp. 420-427, 2007. 
[71] Wolf, I. \& Brumme, R., Dinitrogen and nitrous oxide formation in beech forest floor and mineral soils. Soil Science Society of America Journal, 67, pp. 1862-1868, 2003.

[72] Xue, Y., Kovacic, D.A., David, M.B., Gentry, L.E., Mulvaney, R.L. \& Lindau, C.W., In situ measurements of denitrification in constructed wetlands. Journal of Environmental Quality, 28(1), pp. 263-269, 1999.

[73] Zhu, R., Sun, L. \& Ding, W., Nitrous oxide emissions from tundra soil and snowpack in the maritime Antarctic. Chemosphere, 59, pp. 1667-1675, 2005.

[74] Huang, B., Chen, G., Huang, G. \& Tsuruta, H., Nitrous oxide emission from temperate meadow grassland and emission estimation for temperate grassland of China. Nutrient Cycling in Agroecosystems, 67, pp. 31-36, 2003.

[75] Mosier, A.R. \& Delgado, J.A., Methane and nitrous oxide fluxes in grasslands in Western Puerto Rico. Chemosphere, 35(9), pp. 2059-2082, 1997.

[76] Dobbie, K.E. \& Smith, K.A., The effect of water table depth on emissions of $\mathrm{N}_{2} \mathrm{O}$ from a grassland soil. Soil Use and Management, 22, pp. 22-28, 2006.

[77] Bedard-Haughn, A., Matson, A.L. \& Pennock, D.J., Land use effects on gross nitrogen mineralization, nitrification, and $\mathrm{N}_{2} \mathrm{O}$ emissions in ephemeral wetlands. Soil Biology and Biochemistry, 38, pp. 3398-3406, 2006.

[78] Groffman, P.M., Brumme, R., Butterbach-Bahl, K., Dobbie, K.E., Mosier, A.R., Ojima, D., Papen, H., Parton, W.J., Smith, K.A. \& Wagner-Riddle, C.; Evaluating annual nitrous oxide fluxes at the ecosystem scale. Global Biogeochemical Cycles, 14(4), pp. 1061-1070, 2000.

[79] Ambus, P. \& Robertson, G.P., The effect of increased N deposition on nitrous oxide, methane and carbon dioxide fluxes from unmanaged forest and grassland communities in Michigan. Biogeochemistry, 79, pp. 315-337, 2006.

[80] Ambus, P., Zechmeister-Boltenstern, S. \& Butterbach-Bahl, K., Sources of nitrous oxide emitted from European forest soils. Biogeosciences, 3, pp. 135-145, 2006.

[81] Holtan-Hartwig, L., Dörsch, P. \& Bakken, L.R., Low temperature control of soil denitrifying communities; kinetics of $\mathrm{N}_{2} \mathrm{O}$ production and reduction. Soil Biology and Biochememistry, 34(11), pp. 1797-1806, 2002.

[82] Groffman, P.M., Hardy, J.P., Driscoll, C.T. \& Fahey, T.J., Snow depth, soil freezing, and fluxes of carbon dioxide, nitrous oxide and methane in a northern hardwood forest. Global Change Biology, 12(9), pp. 1748-1760, 2006.

[83] Mørkved, P.T., Dörsch, P., Henriksen, T.M. \& Bakken, L.R., $\mathrm{N}_{2} \mathrm{O}$ emissions and product ratios of nitrification and denitrification as affected by freezing and thawing. Soil Biology and Biochemistry, 38, pp. 3411$3420,2006$. 
[84] Teepe R., Brumme, R. and Beese, F., Nitrous oxide emissions from soil during freezing and thawing periods. Soil Biology and Biochemistry, 33, pp. 1269-1275, 2001.

[85] Röver, M., Heinemeyer, O. \& Kaiser, E.A., Microbial induced nitrous oxide emissions from an arable soil during winter. Soil Biology and Biochemistry, 30, pp. 1859-1865, 1998.

[86] Regina, K., Syväsalo, E., Hannukkala, A. \& Esala, M., Fluxes of $\mathrm{N}_{2} \mathrm{O}$ from farmed peat soils in Finland. European Journal of Soil Science, 55, pp. 591599, 2004.

[87] Teepe, R., Vor, A., Beese, F., \& Ludwig, B., Emissions of $\mathrm{N}_{2} \mathrm{O}$ from soils during cycles of freezing and thawing and the effects of soil water, texture and duration of freezing. European Journal of Soil Science, 55, pp. 357365, 2004.

[88] Song, C., Wang, Y., Wang, Y. \& Zhao, Z., Emission of $\mathrm{CO}_{2}, \mathrm{CH}_{4}$ and $\mathrm{N}_{2} \mathrm{O}$ from freshwater marsh during freeze-thaw period in Northeast of China. Atmospheric Environment, 40, pp. 6879-6885, 2006.

[89] Walker, J.T., Geron, C.D., Vose, J.M. \& Swank, W.T., Nitrogen trace gas emissions from a riparian ecosystem in southern Appalachia. Chemosphere, 49, pp. 1389-1398. 2002.

[90] Luo, J., Lindsey, S.B. \& Ledgard, S.F., Nitrous oxide emissions from animal urine application bon a New Zealand pasture. Biology and Fertility of Soils, 44, pp. 463-470. 2008.

[91] Maag, M. \& Vinther, F.P., Nitrous oxide emission by nitrification and denitrification in different soil types and at different soil moisture contents and temperatures. Applied Soil Ecology, 4, pp. 5-14, 1996.

[92] Rudaz, A.O., Wälti, E., Kyburz, G., Lehmann, P. \& Fuhrer, J., Temporal variation in $\mathrm{N}_{2} \mathrm{O}$ and $\mathrm{N}_{2}$ fluxes from a permanent pasture in Switzerland in relation to management, soil water content and soil temperature. Agriculture, Ecosystems and Environment, 73, pp. 83-91, 1999.

[93] Venterink, H.O., Hummelink, E. \& Van den Hoorn, M.W., Denitrification potential of a river floodplain during flooding with nitrate-rich water: grasslands versus reedbeds. Biogeochemistry, 65(2), pp. 233-244, 2003.

[94] Priemé, A. \& Christensen, S., Natural perturbations, drying-wetting and freezing-thawing cycles, and the emission of nitrous oxide, carbon dioxide and methane from farmed organic soils. Soil Biology and Biochemistry, 33, pp. 2083-2091, 2001.

[95] Hendriks, D.M.D, Van Huissteden, J., Dolman, A.J. \& van der Molen, M.K., The full greenhouse gas balance of an abandoned peat meadow. Biogeosciences, 4, pp. 411-424, 2007.

[96] Maljanen, M., Hytönen, J. \& Martikainen. P.J., Fluxes of $\mathrm{N}_{2} \mathrm{O}, \mathrm{CH}_{4}$ and $\mathrm{CO}_{2}$ on afforested boreal agricultural soils. Plant and Soil, 231, pp. 113$121,2001$. 